\title{
Second Law assessment of binary plants generating power from low-temperature geothermal fluids
}

\author{
Ronald DiPippo* \\ University of Massachusetts Dartmouth, 285 Old Westport Road, North Dartmouth, MA 02747-2300, USA
}

Received 11 April 2003; accepted 23 October 2003

Available online 24 April 2004

\begin{abstract}
Binary-type energy conversion systems are typically used to exploit low-temperature geothermal resources. There are many different technical variations of binary plants, including those known as Organic Rankine Cycles (ORC) and proprietary systems known as Kalina cycles. Recent articles in the technical literature claim dramatic efficiency advantages for Kalina cycles over ORCs, thereby providing the motivation for this study. Claims of remarkable superiority for one type of technology relative to another ought to be verifiable by recourse to actual performance data. Since there is now an actual Kalina cycle in operation, it ought to be possible to make a comparison between it and ORC plants that have been in operation for some time. Comparisons between power plants must use an appropriate and consistent thermodynamic basis. It has been shown that the Second Law of thermodynamics is the best basis for such comparisons. This principle, employing the concept of exergy, is used here to shed light on these claims. Furthermore, we introduce a methodology to render the comparison of plant efficiencies on common input and environmental conditions, even though the plants being compared operate with somewhat different fluid inlet and ambient temperatures.
\end{abstract}

(c) 2004 CNR. Published by Elsevier Ltd. All rights reserved.

Keywords: Geothermal power plants; Binary power plants; Organic Rankine Cycles; Kalina cycles; Low-temperature fluids

\section{Introduction}

Low-temperature geothermal resources, typically $150^{\circ} \mathrm{C}\left(300^{\circ} \mathrm{F}\right)$ or less, are usually exploited by means of binary-type energy conversion systems. Such systems employ a secondary working fluid within a closed Rankine cycle. There are many technical variations on

\footnotetext{
* Tel.: +1-508-999-8541; fax: +1-508-999-8881.

E-mail address: rdipippo@umassd.edu (R. DiPippo).
} 


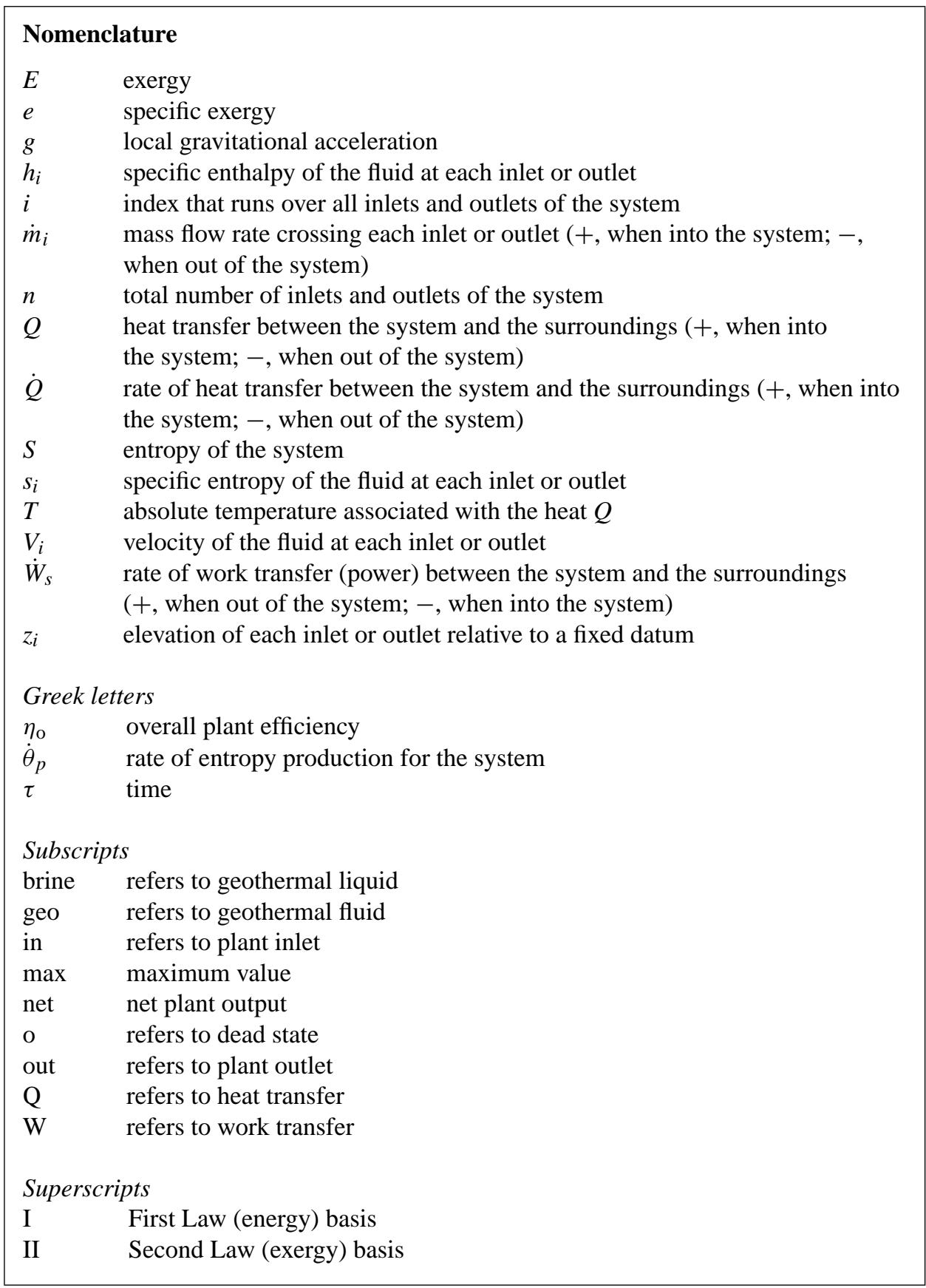


this type of plant, including those known as Organic Rankine Cycles (ORCs) and proprietary systems known as Kalina cycles.

This study was motivated by recent articles proclaiming dramatic efficiency advantages for Kalina cycles over ORCs (Liebowitz and Mlcak, 1999; Mlcak, 2002; Mlcak et al., 2002). With the exception of the 2002 articles, papers on the Kalina cycles have presented their theoretical advantages (Kalina and Liebowitz, 1989, 1994; Liebowitz and Markus, 1990; Kalina et al., 1995). Claims of remarkable superiority for one type of technology relative to another ought to be verifiable by recourse to actual performance data now that there is an actual Kalina cycle in operation.

When drawing comparisons between power plants, it is important to use a thermodynamically consistent basis. DiPippo and Marcille (1984) have shown the advantage of basing efficiency calculations and, by extension, comparisons between plants on the Second Law of thermodynamics. This technique, using the concept of exergy, will be used later in this paper to shed some light on these claims.

\section{Fundamentals of Second Law analysis}

In this section, we present the fundamental principles that will underpin the analysis to follow. Let us begin with the basic concepts and working equations that derive from the laws of thermodynamics as applied to open systems in the absence of chemical reactions. The general Second Law formulation for open systems is given as

$$
\dot{\theta}_{p}=\frac{\mathrm{d} S}{\mathrm{~d} \tau}-\sum_{i=1}^{n} \dot{m}_{i} s_{i}-\int_{\tau_{1}}^{\tau_{2}} \frac{1}{T} \frac{\delta Q}{\delta \tau}
$$

We will deal here only with steady systems; therefore, all time derivatives of thermodynamic properties will vanish, leading to our working equation:

$$
\dot{\theta}_{p}=-\sum_{i=1}^{n} \dot{m}_{i} s_{i}-\int_{\tau_{1}}^{\tau_{2}} \frac{1}{T} \frac{\delta Q}{\delta \tau}
$$

The physical meaning of the integral in Eq. (2) is that it represents a summation, taken during the duration of the process, of all the incremental heat transfer rates divided by their corresponding absolute temperatures over the entire surface area of the open system.

In analyzing any system it will always be necessary to augment Eqs. (1) and (2) with equations expressing conservation of both energy and mass. Applying the First Law of thermodynamics for open systems operating in steady state yields the working equation

$$
\dot{Q}-\dot{W}_{s}=-\sum_{i=1}^{n} \dot{m}_{i}\left(h_{i}+0.5 V_{i}^{2}+g z_{i}\right)
$$

For an open, steady-state system, conservation of mass requires that

$$
\sum_{i=1}^{n} \dot{m}_{i}=0
$$




\section{Exergy and its application to mass flows and heat and work transfers}

The concept of exergy (sometimes called available work) relates to the maximum work (or power) output that could theoretically be obtained from any system relative to given surroundings. Again, we will discuss only open, steady, non-reacting systems. The system may receive or discharge fluids from or to the surroundings, and exchange heat and work with the surroundings. To obtain the maximum output from any system, two conditions must be met:

1. All processes taking place within the system must be ideally reversible.

2. The state of all fluids being discharged from the system must be in thermodynamic equilibrium with the surroundings.

We often refer to the state of the surroundings as the dead state because when fluids are in thermodynamic equilibrium with the surroundings there is no potential for doing work, and the fluid may be considered "dead."A consequence of the first condition is that $\dot{\theta}_{p}$ in Eq. (2) vanishes:

$$
-\sum_{i=1}^{n} \dot{m}_{i} s_{i}-\int_{\tau_{1}}^{\tau_{2}} \frac{1}{T} \frac{\delta Q}{\delta \tau}=0
$$

Next we can use the two conditions to specialize the First and Second Law equations to arrive at the exergy working equation for a fluid. Let us consider a simplified system with only two channels: one inlet (state 1) and one outlet (state 2). Also, let us for the moment ignore the effects of kinetic and potential energy. Then, Eq. (3) becomes

$$
\dot{Q}-\dot{W}=\dot{m}\left(h_{2}-h_{1}\right)
$$

where the subscript $s$ on the power in Eq. (3) has been dropped for clarity. Since the only heat transfer is between the system and the dead state, Eqs. (6) and (5) can be rewritten, respectively, as:

$$
\dot{Q}_{\mathrm{o}}-\dot{W}=\dot{m}\left(h_{2}-h_{1}\right)
$$

and

$$
-\dot{m}\left(s_{1}-s_{2}\right)-\frac{\dot{Q}_{\mathrm{o}}}{T_{\mathrm{o}}}=0
$$

Eliminating $\dot{Q}_{\mathrm{o}}$, one obtains

$$
\dot{W}=\dot{m}\left[h_{1}-h_{2}-T_{\mathrm{o}}\left(s_{1}-s_{2}\right)\right]
$$

Finally, we use the second condition to stipulate that the exit state be identical to the dead state, and so obtain the maximum power output:

$$
\dot{W}_{\max }=\dot{m}\left[h_{1}-h_{\mathrm{o}}-T_{\mathrm{o}}\left(s_{1}-s_{\mathrm{o}}\right)\right]
$$

The expression in brackets is given a distinctive name, the specific exergy, $e$ :

$$
e_{1} \equiv h_{1}-h_{\mathrm{o}}-T_{\mathrm{o}}\left(s_{1}-s_{\mathrm{o}}\right)
$$


Thus, Eq. (11) may be used to find the specific exergy of any fluid stream at a temperature $T_{1}$ and pressure $P_{1}$, relative to a given set of ambient conditions $T_{\mathrm{o}}$ and $P_{\mathrm{o}}$.

For a fluid flowing at a certain mass flow rate, multiplying the specific exergy by the mass flow rate results in the maximum power output theoretically obtainable from the given fluid for the given surroundings; we will call this the exergetic power. Instead of using the symbol $\dot{W}_{\text {max }}$ as in Eq. (10), we will henceforth use a new symbol, $\dot{E}$, for this important quantity.

If kinetic or potential energy effects are important, the enthalpy $h_{1}$ should be augmented by $0.5 V_{1}^{2}$ or $g z_{1}$, respectively. Since state 1 is really arbitrary, we can drop the subscript 1 and obtain a general expression:

$$
e=h-h_{\mathrm{o}}-T_{\mathrm{o}}\left(s-s_{\mathrm{o}}\right)
$$

where the properties at the dead state are evaluated at $T_{\mathrm{o}}$ and $P_{\mathrm{o}}$. When the fluid is in the liquid phase at the dead-state conditions, as is usually the case, it is sufficiently accurate to take the dead-state enthalpy and entropy values as if the fluid were a saturated liquid at the dead-state temperature, $T_{\mathrm{o}}$.

Whenever heat is transferred between systems, a certain amount of exergy is also transferred. This is very important in the design of heat exchangers for geothermal binary plants. The main point in such a case is this: the absolute amount of exergy given up by the hotter system is, in reality, always less than the exergy received by the cooler system; only in the ideal case of reversible heat transfer are the two exergy amounts equal. High efficiency heat exchangers minimize the destruction of exergy during the heat transfer process.

The magnitude of the exergy involved with the heat transfer process can be found from the basic notion of exergy. It is the maximum work that could be produced on a continuous basis from the given amount of heat. That is, it is the work that could be obtained using a reversible Carnot cycle operating between the temperature from which the heat is received and the ambient temperature.

Thus, if a quantity of heat $Q$ is transferred from a system at an absolute temperature $T$ to another system at some lower temperature in an environment having a dead-state temperature $T_{\mathrm{o}}$, the exergy $E_{Q}$ associated with the heat $Q$ is given by:

$$
E_{Q}=\left(1-\frac{T_{\mathrm{o}}}{T}\right) Q
$$

where the factor in parentheses is the Carnot efficiency for an ideal cycle operating between $T$ and $T_{\mathrm{o}}$ (Bosnjakovic, 1965).

When a system experiences a work transfer process with its surroundings, exergy is also transferred. In this case the exergy associated with the work is simply the maximum work that can be delivered in the absence of any dissipative phenomena, and therefore is exactly equal to the amount of work itself. Thus, the exergy $E_{W}$ associated with the transfer of an amount of work $W$ is given by:

$$
E_{W}=W
$$

It should be noted that both Eqs. (13) and (14) may be written as rate equations involving the thermal power $\dot{Q}$ or mechanical power $\dot{W}$, respectively. The equations will then yield the rate of exergy transfer or the exergetic power (Bosnjakovic, 1965). 


\section{Exergy efficiencies}

It is very useful to define efficiencies based on exergy (sometimes called Second Law efficiencies). Whereas there is no standard set of definitions in the literature, we will focus on two different approaches-one we will call "brute-force" and the other will be called "functional."

- A "brute-force" exergy efficiency for any system is defined as the ratio of the sum of all output exergy terms to the sum of all input exergy terms.

- A "functional" exergy efficiency for any system is defined as the ratio of the exergy associated with the desired energy output to the exergy associated with the energy expended to achieve the desired output.

It is clear that the brute-force definition can be applied in a straightforward manner, irrespective of the nature of the component, once all exergy flows have been determined. The functional definition, however, requires judgment and a clear understanding of the purpose of the system under consideration before the working equation for the efficiency can be formulated.

When this concept is applied to a power plant as a whole, the overall exergetic efficiency reduces to a very simple formula, namely, the ratio of the net power output to the exergy of the motive fluid serving as the energy source for the plant (DiPippo and Marcille, 1984). That is:

$$
\eta_{\mathrm{o}}^{\mathrm{II}}=\frac{\dot{W}_{\text {net }}}{\dot{E}_{1}}
$$

This formulation may be viewed as absolute, i.e., both functional and brute-force, in that we attribute zero exergy to the leaving fluid in a practical sense, even if it carries exergy in the thermodynamic sense. That is, we assume that no further use is made of the exiting fluid. If the fluid is used, say, for direct heating after leaving the plant, then the exergetic value of that usage should be added to the numerator of Eq. (15), thereby raising the overall exergetic efficiency (DiPippo, 1987).

This approach allows us to compare plants of different types operating under different inlet and dead-state conditions on the same thermodynamic basis, namely, how well the plant converts the available incoming thermodynamic power into actual usable power given the characteristics of the heat source and environment.

The two exergy efficiency definitions given in Section 4 may be applied in an encyclopedic manner to the various components that comprise a geothermal power plant (DiPippo, 1994), but since we are concerned in this paper with comparisons of plants at the overall level, we will not perform a component analysis here.

\section{Second Law analysis of selected binary plants}

In this section we will focus on a few binary geothermal energy conversion systems with the aim of illustrating how the methodology developed in earlier sections can be applied as a performance assessment tool. The case studies selected include binary power plants of different types. In each case, we will calculate the overall plant efficiency. 


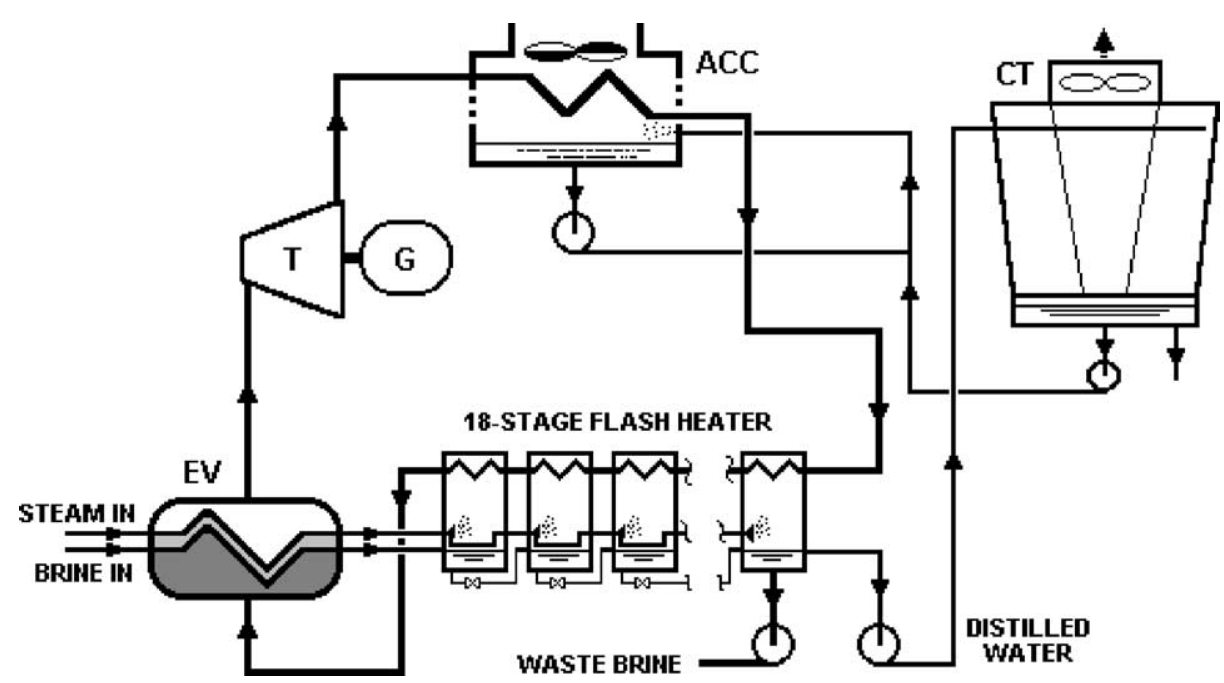

Fig. 1. Otake pilot binary plant. ACC: air-cooled condenser; CT: cooling tower; EV: evaporator; G: generator; T: turbine.

\subsection{Otake pilot binary geothermal power plant}

Otake, on the Japanese island of Kyushu, was the site of one of the most intriguing geothermal binary power plants (DiPippo, 1980a). The plant had a rated power of $1000 \mathrm{~kW}$ and received both steam and brine from the adjacent $10 \mathrm{MW}$ Otake flash-steam plant. It used a unique 18-stage flash evaporator to efficiently heat isobutane, the cycle working fluid (see Fig. 1). The relevant plant data are given in Table 1.

From these data, it is easy to calculate the exergetic efficiency of the plant:

$$
\begin{aligned}
\eta_{\mathrm{o}}^{\mathrm{II}} & =\frac{\dot{W}_{\text {net }}}{\dot{E}_{\text {in }}}=\frac{\dot{W}_{\text {net }}}{\dot{m}_{\text {geo }}\left(e_{\text {geo, in }}\right)}=\frac{1000 \mathrm{~kW}}{(14.661 \mathrm{~kg} / \mathrm{s}) \times(126.65 \mathrm{~kJ} / \mathrm{kg})} \\
& =\frac{1000 \mathrm{~kW}}{1856.9 \mathrm{~kW}}=0.539
\end{aligned}
$$

Table 1

Operating data for Otake pilot binary plant

\begin{tabular}{lc}
\hline Item & Data \\
\hline Steam inlet temperature $\left({ }^{\circ} \mathrm{C}\right)$ & 130 \\
Steam flow rate $(\mathrm{kg} / \mathrm{s})$ & 1.305 \\
Brine inlet temperature $\left({ }^{\circ} \mathrm{C}\right)$ & 130 \\
Brine flow rate $(\mathrm{kg} / \mathrm{s})$ & 14.661 \\
Geofluid flow rate $($ total $)(\mathrm{kg} / \mathrm{s})$ & 50 \\
Geofluid outlet temperature $\left({ }^{\circ} \mathrm{C}\right)$ & 1000 \\
Plant rated power $(\mathrm{kW})$ & 18 \\
Dead-state temperature $\left({ }^{\circ} \mathrm{C}\right)$ & \\
\hline
\end{tabular}


This value, $53.9 \%$, is the highest exergy conversion efficiency of any binary plant that the author has ever seen. It must be pointed out, however, that the inlet fluid contains steam and brine, giving a relatively high value for the incoming exergy. The extremely efficient 18-stage flash evaporator is a key to the high performance. By using so many stages, there is an incremental heating process during which the temperature difference between the geofluid and the isobutane is kept very small. This reduces the exergy loss during the heat transfer process. The plant also incorporated a recuperator (or feedwater heater) that used a bleed stream of isobutane from the turbine, which also contributed to the very high overall plant conversion efficiency.

By comparison, the First Law thermal efficiency is not very impressive:

$$
\begin{aligned}
\eta_{\mathrm{o}}^{\mathrm{I}} & =\frac{\dot{W}_{\text {net }}}{\dot{Q}_{\text {in }}}=\frac{\dot{W}_{\text {net }}}{\dot{m}_{\text {geo }}\left(h_{\text {in }}-h_{\text {out }}\right)}=\frac{1000 \mathrm{~kW}}{(14.661 \mathrm{~kg} / \mathrm{s}) \times(739.84-209.33) \mathrm{kJ} / \mathrm{kg}} \\
& =\frac{1000 \mathrm{~kW}}{7777.9 \mathrm{~kW}}=0.129
\end{aligned}
$$

Interestingly, this value of $12.9 \%$ shows that a binary plant with an extremely high Second Law efficiency nevertheless is a relatively poor converter of heat into work. As a footnote, this plant was tested and then dismantled. No plant of a similar design has ever been built again, most likely indicating that the economics were unfavorable.

\subsection{Nigorikawa binary geothermal power plant}

Another pilot binary plant, the Nigorikawa (or Mori) plant, was built by the Japanese near Hakodate on Hokkaido, contemporaneously with the Otake pilot plant (DiPippo, 1980b). This plant also was rated at $1000 \mathrm{~kW}$ but used a simple binary cycle (see Fig. 2). The plant incorporated a two-stage condenser, which is not shown in the simplified schematic.

The cycle working fluid was Refrigerant-114 $\left(\mathrm{C}_{2} \mathrm{Cl}_{2} \mathrm{~F}_{4}\right)$. Table 2 gives the specifications.

In contrast with the high-efficiency Otake binary plant, the Nigorikawa unit had exergetic and thermal efficiencies typical of binary plants:

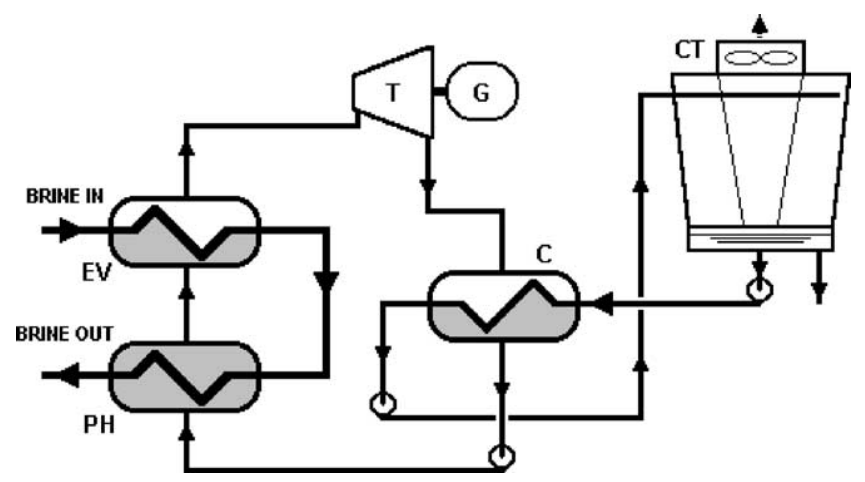

Fig. 2. Nigorikawa (Mori) binary plant. C: condenser; PH: preheater; see also Fig. 1. 
Table 2

Operating data for Nigorikawa binary plant

\begin{tabular}{lc}
\hline Item & Data \\
\hline Brine inlet temperature $\left({ }^{\circ} \mathrm{C}\right)$ & 140 \\
Brine outlet temperature $\left({ }^{\circ} \mathrm{C}\right)$ & 92 \\
Brine flow rate $(\mathrm{kg} / \mathrm{s})$ & 49.996 \\
Plant rated power $(\mathrm{kW})$ & 1000 \\
Dead-state temperature $\left({ }^{\circ} \mathrm{C}\right)$ & 13 \\
\hline
\end{tabular}

$$
\begin{aligned}
\eta_{\mathrm{o}}^{\mathrm{II}} & =\frac{\dot{W}_{\text {net }}}{\dot{E}_{\text {in }}}=\frac{\dot{W}_{\text {net }}}{\dot{m}_{\text {geo }}\left(e_{\text {geo,in }}\right)}=\frac{1000 \mathrm{~kW}}{(49.996 \mathrm{~kg} / \mathrm{s}) \times(92.772 \mathrm{~kJ} / \mathrm{kg})} \\
& =\frac{1000 \mathrm{~kW}}{4638.2 \mathrm{~kW}}=0.216
\end{aligned}
$$

and

$$
\begin{aligned}
\eta_{\mathrm{o}}^{\mathrm{I}} & =\frac{\dot{W}_{\text {net }}}{\dot{Q}_{\text {in }}}=\frac{\dot{W}_{\text {net }}}{\dot{m}_{\text {geo }}\left(h_{\text {in }}-h_{\text {out }}\right)}=\frac{1000 \mathrm{~kW}}{(49.996 \mathrm{~kg} / \mathrm{s}) \times(589.13-385.33) \mathrm{kJ} / \mathrm{kg}} \\
& =\frac{1000 \mathrm{~kW}}{10189 \mathrm{~kW}}=0.0981
\end{aligned}
$$

Like the Otake pilot plant, the Nigorikawa plant was also dismantled after its test period was concluded.

\subsection{Heber SIGC geothermal power plant}

A multi-unit advanced binary plant has been in operation at the Heber geothermal field in the Imperial Valley, CA, since June 1993 (GRC Bulletin, 1993). The plant consists of six integrated dual-level units. Brine is pumped from the reservoir and arrives at the plant at a temperature of $165^{\circ} \mathrm{C}$, somewhat higher than for a typical "low-temperature" plant. A simplified schematic is shown in Fig. 3.

The upper cycle that includes evaporator EV1 and preheater PH1 produces more power than the lower cycle: $4260 \mathrm{~kW}$, gross versus $3015 \mathrm{~kW}$, gross. There is an auxiliary load of $400 \mathrm{~kW}$ for the unit, yielding a net power of $6875 \mathrm{~kW}$.

An exergy analysis of this plant can be conducted knowing only the brine inlet temperature and flow rate, together with the net power output. Since this plant uses water cooling towers, the lowest possible cooling water temperature is the wet-bulb temperature; the design value at Heber is $27^{\circ} \mathrm{C}$. However, on the day the data used in the calculations were taken, the cooling water inlet temperature to the condensers was given as $20^{\circ} \mathrm{C}$, meaning that the wet-bulb temperature had to be about $5-7^{\circ} \mathrm{C}$ below the inlet water temperature.

Adopting a dead-state temperature of $15^{\circ} \mathrm{C}$, we can calculate the exergetic efficiency as follows:

$$
\eta_{\mathrm{o}}^{\mathrm{II}}=\frac{\dot{W}_{\text {net }}}{\dot{E}_{\text {in }}}=\frac{\dot{W}_{\text {net }}}{\dot{m}_{\text {brine }}\left(e_{\text {brine, in }}\right)}=\frac{6875 \mathrm{~kW}}{(126 \mathrm{~kg} / \mathrm{s}) \times(125.84 \mathrm{~kJ} / \mathrm{kg})}=\frac{6875 \mathrm{~kW}}{15856 \mathrm{~kW}}=0.434
$$




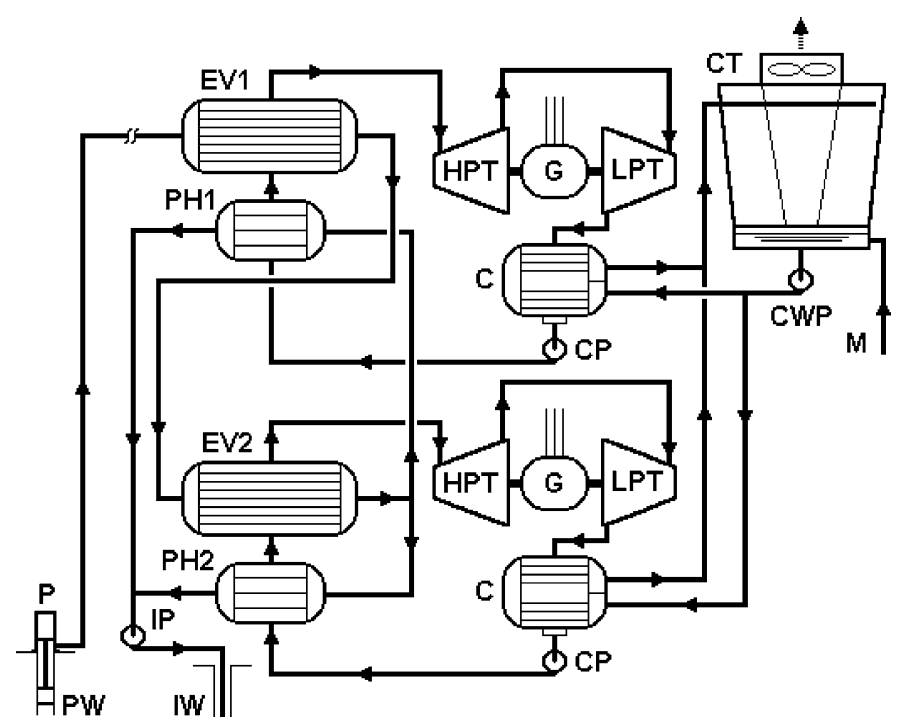

Fig. 3. Simplified schematic of Heber SIGC power plant. CP: condensate pump; CWP: cooling water pump; HPT, LPT: high-, low-pressure turbine; IP: injection pump; IW: injection well; P: pump; PW: production well; see also Fig. 1.

Thus, the overall plant Second Law efficiency is an impressive $43.4 \%$.

The functional efficiency, based on the exergy drop of the brine passing through the plant, is obtained as follows:

$$
\begin{aligned}
\eta_{\mathrm{o}}^{\mathrm{II}} & =\frac{\dot{W}_{\text {net }}}{\Delta \dot{E}_{\text {brine }}}=\frac{\dot{W}_{\text {net }}}{\dot{m}_{\text {brine }}\left(e_{\text {brine, } \text { in }}-e_{\text {brine }, \text { out }}\right)}=\frac{6875 \mathrm{~kW}}{(126 \mathrm{~kg} / \mathrm{s}) \times(125.84-18.22) \mathrm{kJ} / \mathrm{kg}} \\
& =\frac{6875 \mathrm{~kW}}{13560 \mathrm{~kW}}=0.507
\end{aligned}
$$

Thus, the plant converts $50.7 \%$ of the exergy given up by the brine into electric power. The cascaded use of the brine in two sets of evaporators has improved the temperature match between the brine and the cycle working fluids, resulting in a high conversion efficiency.

However, as was seen in the case of the Otake pilot binary plant, the First Law efficiency for the plant is much lower:

$$
\begin{aligned}
\eta_{\mathrm{o}}^{\mathrm{I}} & =\frac{\dot{W}_{\text {net }}}{\dot{Q}_{\text {in }}}=\frac{\dot{W}_{\text {net }}}{\dot{m}_{\text {brine }}\left(h_{\text {brine, in }}-h_{\text {brine }, \text { out }}\right)}=\frac{6875 \mathrm{~kW}}{(126 \mathrm{~kg} / \mathrm{s}) \times(697.34-284.61) \mathrm{kJ} / \mathrm{kg}} \\
& =\frac{6875 \mathrm{~kW}}{52004 \mathrm{~kW}}=0.132
\end{aligned}
$$

Thus, $13.2 \%$ of the heat added to the Ormat dual-level binary cycle is converted into useful work output. 


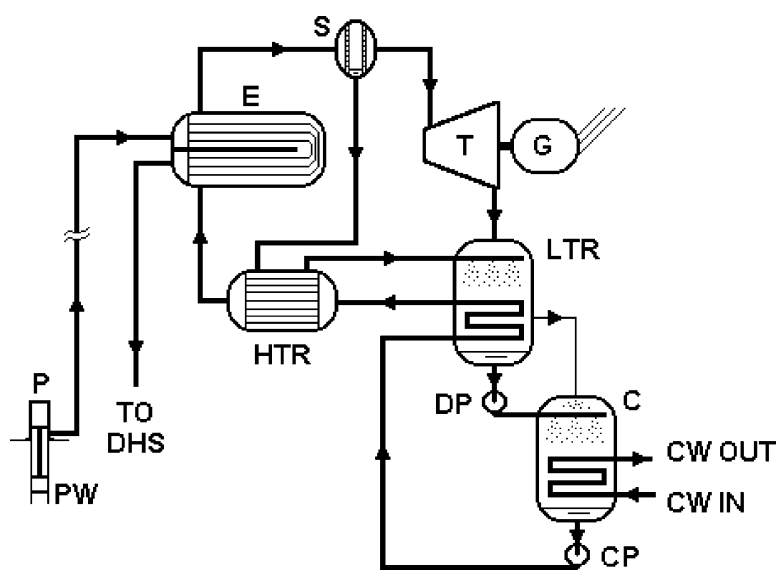

Fig. 4. Simplified schematic of Húsavík power plant. CW: cooling water; DHS: district heating system; DP: drain pump; E: evaporator; HTR, LTR: high-, low-temperature recuperator; see also Fig. 1.

\subsection{Húsavík Kalina cycle power plant}

The Kalina KCS-34 binary power plant at Húsavík, Iceland, is shown in simplified schematic form in Fig. 4 (Mlcak et al., 2002).

The working fluid is a mixture of $82 \%$ ammonia and $18 \%$ water. This composition was optimized to match the temperature of the brine stream. The main advantage of the mixed working fluid is its variable-temperature evaporation and condensation in contrast to a pure fluid at subcritical pressures that evaporates and condenses at constant temperature. In principle, this allows a closer approach between the brine cooling line and the working fluid evaporation line in the evaporator, and a closer approach between the working fluid condensation line and the cooling water heating line in the condenser.

It should be noted that pure fluids at supercritical pressures also transition from liquid to vapor at variable temperature without passing through the liquid-vapor region of the thermodynamic phase space. This feature has been used in simple binary plants using pure fluids to improve the exergy transfer in the evaporator, but the condenser still would exhibit a pronounced pinch-point.

The Húsavík plant will be analyzed using the exergy methodology. Table 3 shows the design data that were reported recently (Mlcak et al., 2002). The authors did not explicitly state the design power output from the plant, but in other references to the plant, it is called a 2 MW plant. Liebowitz and Mlcak (1999) gave the expected operating parameters for this plant as follows: $\dot{W}_{\text {net }}=2030 \mathrm{~kW}$ using $90 \mathrm{~kg} / \mathrm{s}$ of brine at $124{ }^{\circ} \mathrm{C}$, together with $182 \mathrm{~kg} / \mathrm{s}$ of cooling water at $5^{\circ} \mathrm{C}$. The reported actual performance does not quite meet these expectations.

Actual test data for two separate days were provided (see Table 4). The dead-state temperature was taken as $5^{\circ} \mathrm{C}$.

From this information, we can calculate exergetic efficiencies for the actual operation of the plant. The fact that once-through cooling is available from a cold river is an important 
Table 3

Húsavík KCS-34 plant design specifications (Mlcak et al., 2002)

\begin{tabular}{llll}
\hline Condition & Temperature $\left({ }^{\circ} \mathrm{C}\right)$ & Pressure (bar) & $\mathrm{NH}_{3}$ (wt.\%) \\
\hline Brine inlet to evaporator & 124 & n.a. & - \\
Brine outlet from evaporator & 80 & n.a. & - \\
Working fluid out of CP and into LTR & 13 & n.a. & 82 \\
Working fluid out of HTR & 68 & n.a. & 82 \\
Working fluid out of evaporator & 121 & n.a. & 95 \\
Working fluid vapor out of S & 121 & n.a. & 5 \\
Working fluid liquid out of S & 121 & n.a. & 5 \\
Working fluid liquid out of HTR and into LTR & 48 & n.a. & n.a. \\
Working fluid out of turbine & 60 & n.a. & High \\
Working fluid vapor out of LTR & 38 & n.a. & 82 \\
Working fluid liquid out of LTR drain & 38 & 5.4 & - \\
Working fluid out of condenser & 12.4 & n.a. & - \\
Cooling water into condenser & 5 & n.a. & \\
Cooling water out of condenser & 25 & & \\
Brine flow rate: $90 \mathrm{~kg} / \mathrm{s}$ & & & \\
Working fluid flow rate: n.a. & & & \\
Cooling water flow rate: $182 \mathrm{~kg} / \mathrm{s}$ & & & \\
Turbine gross and net power output: n.a. (see text) & & &
\end{tabular}

n.a.: not available.

advantage compared to plants that must use cooling towers or air-cooled condensers. Besides eliminating the usual parasitic power needed to run cooling tower or air-cooled condenser fans, it also eliminates the intermediate heat transfer process between the surroundings and the cooling medium. This latter effect removes the exergetic losses inherent to the heat rejection process.

Thus, we can compute the exergetic efficiency for the conditions on 28 November 2001:

$$
\eta_{\mathrm{o}}^{\mathrm{II}}=\frac{\dot{W}_{\text {net }}}{\dot{E}_{\text {in }}}=\frac{\dot{W}_{\text {net }}}{\dot{m}_{\text {brine }}\left(e_{\text {brine }, \text { in }}\right)}=\frac{1696 \mathrm{~kW}}{(90 \mathrm{~kg} / \mathrm{s}) \times(81.49 \mathrm{~kJ} / \mathrm{kg})}=\frac{1696 \mathrm{~kW}}{7333.9 \mathrm{~kW}}=0.231
$$

Table 4

Operating data for the Húsavík plant (Mlcak et al., 2002)

\begin{tabular}{|c|c|c|}
\hline Item & 28 November 2001 & 29 November 2001 \\
\hline Brine flow rate $(\mathrm{kg} / \mathrm{s})$ & 90 (design) & 90 (design) \\
\hline Brine inlet temperature $\left({ }^{\circ} \mathrm{C}\right)$ & 122 & 121 \\
\hline Cooling water flow rate $(\mathrm{kg} / \mathrm{s})$ & 182 (design) & $202(111 \%$ design $)$ \\
\hline Cooling water inlet temperature $\left({ }^{\circ} \mathrm{C}\right)$ & 5 (design) & 5 (design) \\
\hline Gross electric power $(\mathrm{kW})$ & 1823 & 1836 \\
\hline Auxiliary power $(\mathrm{kW})$ & 127 & 127 \\
\hline Net electric power $(\mathrm{kW})$ & 1696 & 1709 \\
\hline
\end{tabular}


The functional efficiency based on the exergy drop of the brine passing through the plant is:

$$
\begin{aligned}
\eta_{\mathrm{o}}^{\mathrm{II}} & =\frac{\dot{W}_{\text {net }}}{\Delta \dot{E}_{\text {brine }}}=\frac{\dot{W}_{\text {net }}}{\dot{m}_{\text {brine }}\left(e_{\text {brine }, \text { in }}-e_{\text {brine }, \text { out }}\right)}=\frac{1696 \mathrm{~kW}}{(90 \mathrm{~kg} / \mathrm{s}) \times(81.49-36.00) \mathrm{kJ} / \mathrm{kg}} \\
& =\frac{1696 \mathrm{~kW}}{4094.1 \mathrm{~kW}}=0.414
\end{aligned}
$$

Thus, the overall plant Second Law efficiency is $23.1 \%$ and the plant converts $41.4 \%$ of the exergy given up by the brine into electric power.

By contrast, the First Law efficiency for the plant is far lower:

$$
\begin{aligned}
\eta_{\mathrm{o}}^{\mathrm{I}} & =\frac{\dot{W}_{\text {net }}}{\dot{Q}_{\text {in }}}=\frac{\dot{W}_{\text {net }}}{\dot{m}_{\text {brine }}\left(h_{\text {brine, in }}-h_{\text {brine }, \text { out }}\right)}=\frac{1696 \mathrm{~kW}}{(90 \mathrm{~kg} / \mathrm{s}) \times(512.21-334.91) \mathrm{kJ} / \mathrm{kg}} \\
& =\frac{1696 \mathrm{~kW}}{15957 \mathrm{~kW}}=0.106
\end{aligned}
$$

Less than $11 \%$ of the heat added to the KCS-34 cycle is converted into useful work output.

\subsection{Brady bottoming binary cycle}

The final case study is the bottoming binary cycle installed recently as part of the Brady Hot Springs double-flash power plant (Ettinger and Brugman, 1992; Kreiger and Sponsler, 2002). A simple binary plant recovers waste heat from the spent brine leaving the low-pressure flash vessels (see Fig. 5). Operational data from the months of August and September 2002 were made available to the author courtesy of the plant operators, Brady Power Partners (Sponsler, 2002) and were analyzed using the exergetic methodology.

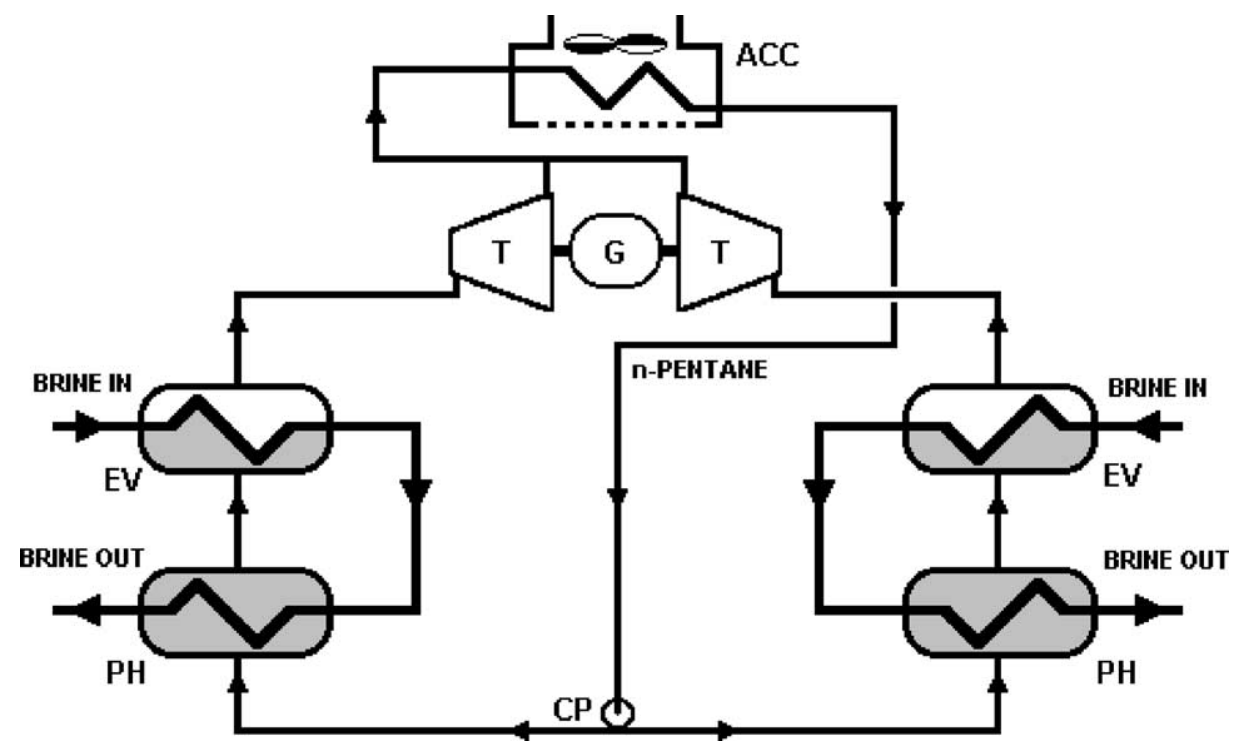

Fig. 5. Brady bottoming binary cycle. See also Figs. 1-3. 
Table 5

Averaged data for Brady bottoming binary cycle: 16-25 September 2002

\begin{tabular}{|c|c|c|c|c|}
\hline Item & 6:00 a.m. & Range & 6:00 p.m. & Range \\
\hline Brine inlet temperature $\left({ }^{\circ} \mathrm{C}\right)$ & 107.8 & $106.0-109.0$ & 108.7 & $105.9-109.3$ \\
\hline Brine outlet temperature $\left({ }^{\circ} \mathrm{C}\right)$ & 81.11 & $79.7-82.7$ & 83.32 & $82.2-84.6$ \\
\hline Brine flow rate $(\mathrm{kg} / \mathrm{s})$ & 484.09 & $474.3-489.7$ & 484.09 & $474.3-489.7$ \\
\hline Ambient temperature $\left({ }^{\circ} \mathrm{C}\right)$ & 16.8 & $11.1-23.3$ & 30.1 & $24.4-35.6$ \\
\hline Gross power $(\mathrm{kW})$ & 5.21 & $4.5-6.0$ & 3.78 & $3.0-4.7$ \\
\hline Auxiliary power (kW) & 0.88 & Constant & 0.88 & Constant \\
\hline Net power & 4.33 & $3.7-5.2$ & 2.90 & $2.2-3.9$ \\
\hline
\end{tabular}

Data for a consecutive 10-day period from 16 to 25 September were collected twice a day, at 6:00 a.m. and at 6:00 p.m. Since the binary plant uses an air-cooled condenser, the performance is sensitive to the ambient temperature. The data allow us to see the effect on performance of variations in the environmental temperature, which was taken as the dead-state temperature for all exergy calculations. Table 5 shows the data for each recording time, averaged over the 10-day period.

With the exception of fairly large fluctuations in the ambient temperature, the other parameters were reasonably constant. A more detailed analysis of the effects of ambient temperature fluctuations on performance will be presented in the next section.

The exergetic efficiency for the morning and evening periods is found as follows:

Morning period

$$
\begin{aligned}
\eta_{\mathrm{o}}^{\text {II }} & =\frac{\dot{W}_{\text {net }}}{\dot{E}_{\text {in }}}=\frac{\dot{W}_{\text {net }}}{\dot{m}_{\text {brine }}\left(e_{\text {brine, in }}\right)}=\frac{4330 \mathrm{~kW}}{(484.09 \mathrm{~kg} / \mathrm{s}) \times(49.861 \mathrm{~kJ} / \mathrm{kg})} \\
& =\frac{4330 \mathrm{~kW}}{24137 \mathrm{~kW}}=0.183
\end{aligned}
$$

Evening period

$$
\begin{aligned}
\eta_{\mathrm{o}}^{\text {II }} & =\frac{\dot{W}_{\text {net }}}{\dot{E}_{\text {in }}}=\frac{\dot{W}_{\text {net }}}{\dot{m}_{\text {brine }}\left(e_{\text {brine, in }}\right)}=\frac{2900 \mathrm{~kW}}{(484.09 \mathrm{~kg} / \mathrm{s}) \times(36.698 \mathrm{~kJ} / \mathrm{kg})} \\
& =\frac{2900 \mathrm{~kW}}{17765 \mathrm{~kW}}=0.168
\end{aligned}
$$

Because of the increase in the ambient temperature during the day, the plant condensers are not able to discharge as much heat in the evening as in the early morning and the power output and efficiency both suffer. The net power falls by over 33\% while the exergetic efficiency drops by about $9 \%$, illustrating the strong effect that ambient temperature has on binary plant performance.

It is interesting to compare the First Law thermal efficiency at the two conditions:

Morning period

$$
\begin{aligned}
\eta_{\mathrm{o}}^{\mathrm{I}} & =\frac{\dot{W}_{\text {net }}}{\dot{Q}_{\text {in }}}=\frac{\dot{W}_{\text {net }}}{\dot{m}_{\text {brine }}\left(h_{\text {brine, in }}-h_{\text {brine,out }}\right)}=\frac{4330 \mathrm{~kW}}{(484.09 \mathrm{~kg} / \mathrm{s}) \times(451.98-339.56) \mathrm{kJ} / \mathrm{kg}} \\
& =\frac{4330 \mathrm{~kW}}{54423 \mathrm{~kW}}=0.081
\end{aligned}
$$


Evening period

$$
\begin{aligned}
\eta_{\mathrm{o}}^{\mathrm{I}} & =\frac{\dot{W}_{\text {net }}}{\dot{Q}_{\text {in }}}=\frac{\dot{W}_{\text {net }}}{\dot{m}_{\text {brine }}\left(h_{\text {brine }, \text { in }}-h_{\text {brine }, \text { out }}\right)}=\frac{2900 \mathrm{~kW}}{(484.09 \mathrm{~kg} / \mathrm{s}) \times(455.79-348.84) \mathrm{kJ} / \mathrm{kg}} \\
& =\frac{2900 \mathrm{~kW}}{51772 \mathrm{~kW}}=0.0576
\end{aligned}
$$

We see that the thermal efficiency is rather low in both cases.

The rise in the heat sink temperature has a far more devastating effect on the thermal efficiency than on the exergetic efficiency. Under the adverse sink temperature, the plant is able to generate only $68 \%$ of the power that it is capable of under more favorable sink conditions. This dramatically illustrates the attention that must be paid to the design of the heat rejection system for plants fed by low-exergy fluids. Improvements in the transfer of exergy at the low-temperature side of the plant will pay excellent dividends in cutting losses during off-design operation.

\section{Kalina versus Organic Rankine Cycles: the case of Húsavík versus Brady}

Recent literature includes claims of impressive efficiency advantages of Kalina cycles over ORCs. Liebowitz and Mlcak (1999), referring to the Kalina KCS-34 cycle, state: "The result is an improvement in net output of $25 \%$ compared to the hydrocarbon ORCs currently available." Mlcak (2002) makes the claim: "A Kalina plant generates 30-50\% more power from a given heat source than an ORC plant." Lewis and Ralph (2002) include this statement in their paper, quoting from another report of theirs: "Preliminary analyses have suggested that the Kalina cycle can provide $15-40 \%$ more net power generation than Rankine cycle designs, using comparable geothermal heat resources."

Since the efficiency of a plant is proportional to its net power output for a given heat input, these statements are equivalent to claims about dramatically superior efficiency for the Kalina cycle over an ORC. We will investigate these claims using the exergetic methodology presented in the preceding sections as applied to actual operating plants of both kinds.

While it is problematic to make direct comparisons between different plants operating at different sites under different conditions, it is nevertheless possible to draw some comparisons between the Húsavík Kalina KCS-34 plant in Iceland and the Brady simple binary cycle that were analyzed in Sections 5.4 and 5.5, respectively. Our intention here is to place these two plants on as common a footing as possible, given the differences that exist in the operating conditions for the two plants, to gain as accurate an assessment of their relative performance as possible.

The most important circumstantial difference between the two plants is that the Húsavík plant is able to take advantage of a very cold Icelandic stream $\left(5^{\circ} \mathrm{C}\right)$ for its cooling system, as it can use a once-through cooling arrangement for the plant condensers. In contrast, the Brady plant uses air-cooled condensers because of the lack of sufficient cooling water in the dry climate of Nevada. The parasitic power requirement of the fans in the air-cooled condensers at Brady is $600 \mathrm{~kW}$, whereas a similar parasitic is absent at Húsavík. In order to assess the relative merits of the two energy conversion systems, we pose the question: 
How would the Brady plant perform if it were able to use the same type of cooling system as the Húsavík plant?

The methodology used to make this comparison is as follows. First, we will use the actual-but different—brine inlet conditions for each plant. It will then be assumed that the Brady plant has a supply of cooling water available that can be used in a once-through cooling system. The temperature of that assumed water supply will be taken as equal to the actual ambient temperature at the Brady plant. This means that the amount of power needed to drive the fans at Brady will be eliminated, thereby increasing the net power by $600 \mathrm{~kW}$.

The Brady plant will then be examined under a series of actual operating conditions with different ambient temperatures - but without the fan parasitic power. For each data point, the exergetic efficiency will be calculated. Finally, we will plot the efficiencies as a function of ambient temperature to detect any trend. Since the lowest ambient temperature at Brady in the available data is about $8^{\circ} \mathrm{C}$, we must extrapolate the results at short distance down to $5^{\circ} \mathrm{C}$ to estimate what the Brady plant efficiency would be if it were afforded the identical cooling medium as the Húsavík plant. This extrapolated efficiency will then be compared to the known efficiency of the Húsavík plant as determined in Section 5.4.

\subsection{Analysis and results}

To facilitate the comparison, see Table 6.

The exergetic efficiency values are plotted in Fig. 6 against the ambient temperature. The data were fitted with the best straight line by the least-squares method, and that line is also shown on the graph. The scatter in the results is caused by insufficient precision in the reported data from the Brady plant; the spreadsheet provided from the plant showed only two significant digits for some of the data including the gross power. Even so, the line

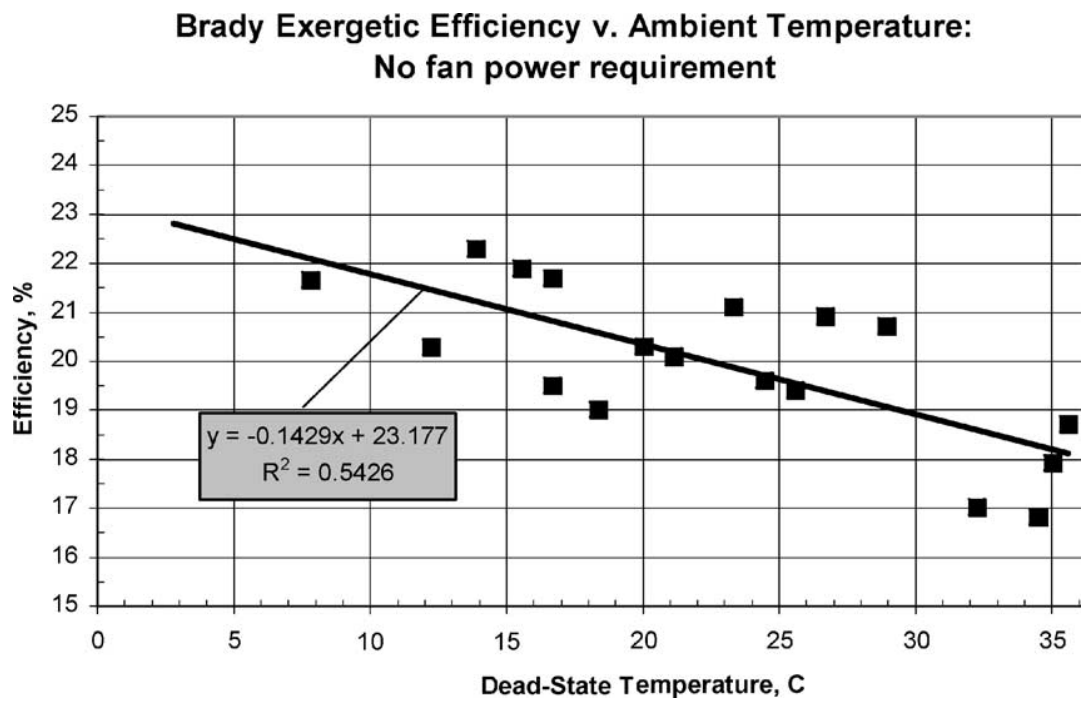

Fig. 6. Brady binary plant exergetic efficiency vs. ambient temperature. 
Table 6

Brady operating data (without fan parasitic power)

\begin{tabular}{|c|c|c|c|c|c|c|c|c|c|}
\hline Item & Brady 1 & Brady 2 & Brady 3 & Brady 4 & Brady 5 & Brady 6 & Brady 7 & Brady 8 & Brady 9 \\
\hline Date & $8 / 21-22 / 02$ & $8 / 24 / 02$ & $9 / 4 / 02$ & $8 / 19 / 02$ & $8 / 23 / 02$ & $9 / 4 / 02$ & $8 / 18 / 02$ & $8 / 17 / 02$ & $8 / 16 / 02$ \\
\hline$T_{\mathrm{o}}\left({ }^{\circ} \mathrm{C}\right)$ & 12.2 & 13.9 & 15.6 & 16.7 & 16.7 & 18.4 & 20.0 & 21.1 & 23.3 \\
\hline$T_{1}\left({ }^{\circ} \mathrm{C}\right)$ & 106.2 & 108.0 & 107.1 & 108.3 & 108.4 & 108.3 & 107.0 & 108.9 & 109.0 \\
\hline$e_{1}(\mathrm{~kJ} / \mathrm{kg})$ & 53.57 & 53.47 & 50.29 & 50.51 & 50.62 & 48.44 & 45.49 & 46.15 & 43.87 \\
\hline$\dot{m}_{b}(\mathrm{~kg} / \mathrm{s})$ & 479.7 & 480.4 & 483.5 & 488.7 & 474.3 & 492.0 & 489.7 & 487.6 & 488.7 \\
\hline$\dot{W}_{g}(\mathrm{~kW})$ & 5500 & 6000 & 5600 & 5100 & 5500 & 4800 & 4800 & 4800 & 4800 \\
\hline$\dot{W}_{p}(\mathrm{~kW})$ & 280 & 280 & 280 & 280 & 280 & 280 & 280 & 280 & 280 \\
\hline$\dot{W}_{n}(\mathrm{~kW})$ & 5220 & 5720 & 5320 & 4820 & 5220 & 4520 & 4520 & 4520 & 4520 \\
\hline$\eta_{\mathrm{o}}^{\mathrm{II}}(\%)$ & 20.3 & 22.3 & 21.9 & 19.5 & 21.7 & 19.0 & 20.3 & 20.1 & 21.1 \\
\hline Item & Brady 10 & Brady 11 & Brady 12 & Brady 13 & Brady 14 & Brady 15 & Brady 16 & Brady 17 & Brady 18 \\
\hline Date & $8 / 20 / 02$ & $8 / 23 / 02$ & $8 / 22 / 02$ & $8 / 24 / 02$ & $8 / 18 / 02$ & $8 / 16 / 02$ & $8 / 19 / 02$ & $8 / 17 / 02$ & $9 / 10 / 02$ \\
\hline$T_{\mathrm{o}}\left({ }^{\circ} \mathrm{C}\right)$ & 24.4 & 25.6 & 26.7 & 28.9 & 32.2 & 34.4 & 35.0 & 35.6 & 7.8 \\
\hline$T_{1}\left({ }^{\circ} \mathrm{C}\right)$ & 108.8 & 108.8 & 108.9 & 109.0 & 109.2 & 109.3 & 109.1 & 109.2 & 107.5 \\
\hline$e_{1}(\mathrm{~kJ} / \mathrm{kg})$ & 42.48 & 41.31 & 40.28 & 38.15 & 35.09 & 33.13 & 32.45 & 32.03 & 60.185 \\
\hline$\dot{m}_{b}(\mathrm{~kg} / \mathrm{s})$ & 482.8 & 477.4 & 477.1 & 483.8 & 489.2 & 488.2 & 486.8 & 488.7 & 486.6 \\
\hline$\dot{W}_{g}(\mathrm{~kW})$ & 4300 & 4100 & 4300 & 4100 & 3200 & 3000 & 3100 & 3200 & 6615 \\
\hline$\dot{W}_{p}^{\circ}(\mathrm{kW})$ & 280 & 280 & 280 & 280 & 280 & 280 & 280 & 280 & 280 \\
\hline$\dot{W}_{n}(\mathrm{~kW})$ & 4020 & 3820 & 4020 & 3820 & 2920 & 2720 & 2820 & 2920 & 6335 \\
\hline$\eta_{\mathrm{o}}^{\text {II }}(\%)$ & 19.6 & 19.4 & 20.9 & 20.7 & 17.0 & 16.8 & 17.9 & 18.7 & 21.6 \\
\hline
\end{tabular}


Table 7

Húsavík performance: data point from 28 November 2001

\begin{tabular}{lc}
\hline Item & Húsavík \\
$T_{\mathrm{o}}\left({ }^{\circ} \mathrm{C}\right)$ & 5 \\
$T_{1}\left({ }^{\circ} \mathrm{C}\right)$ & 122 \\
$e_{1}(\mathrm{~kJ} / \mathrm{kg})$ & 81.49 \\
$\dot{m}_{b}(\mathrm{~kg} / \mathrm{s})$ & 90.0 \\
$\dot{W}_{g}(\mathrm{~kW})$ & 1823 \\
$\dot{W}_{p}(\mathrm{~kW})$ & 127 \\
$\dot{W}_{n}(\mathrm{~kW})$ & 1696 \\
$\eta_{\mathrm{o}}^{\text {II }}(\%)$ & 23.1 \\
\hline
\end{tabular}

is probably the best that can be obtained statistically from the data. Two data points were discarded as erratic-one well above the line $\left(24.5 \%, 26.7^{\circ} \mathrm{C}\right)$ and one well below the line $\left(16.2 \%, 14.4^{\circ} \mathrm{C}\right)$.

The data set from the Húsavík plant for 28 November 2001 was selected for purposes of comparison because it very closely matches the design parameters for the plant as given by Liebowitz and Mlcak (1999). Table 7 summarizes the data and includes the overall exergetic efficiency calculated in Section 5.4.

The correlation for the Brady data set yielded the following equation for the exergetic efficiency as a function of the dead-state temperature:

$$
\eta_{\mathrm{o}}^{\mathrm{II}}=23.177-0.1429 T_{\mathrm{o}}
$$

which can be extrapolated down to a temperature of $5^{\circ} \mathrm{C}$ :

$$
\eta_{\mathrm{o}}^{\mathrm{II}}=23.177-0.1429 T_{\mathrm{o}}=23.177-0.1429 \times 5=22.46 \%
$$

Thus, the results reveal that if the Brady cycle operated with once-through cooling water at $5{ }^{\circ} \mathrm{C}$, it could be reasonably expected to produce an efficiency of about $22.5 \%$. This may be compared with the actual Húsavík efficiency of 23.1\%. The Húsavík Kalina KCS-34 plant would therefore be about $2.6 \%$ more efficient than the Brady ORC plant, under the same cooling conditions.

\subsection{Discussion}

The question remains as to the effect of brine inlet temperature on plant performance. There are two issues here: (1) the Húsavík plant receives brine at $122{ }^{\circ} \mathrm{C}$ whereas the Brady plant receives brine at $108^{\circ} \mathrm{C}$, a difference of $14^{\circ} \mathrm{C}$ and (2) the Húsavík plant received brine $2{ }^{\circ} \mathrm{C}$ below its design value, $122^{\circ} \mathrm{C}$ versus $124^{\circ} \mathrm{C}$. Perhaps the first fact is related to the efficiency advantage of the Húsavík plant over the Brady plant, and perhaps the second fact is the cause of the $334 \mathrm{~kW}$ shortfall in actual power output $-1696 \mathrm{~kW}$ on 28 November 2001 (Mlcak, 2002) versus $2030 \mathrm{~kW}$ at design conditions (Liebowitz and Mlcak, 1999). The shortfall will be examined first.

In a Kalina cycle the $\mathrm{NH}_{3}-\mathrm{H}_{2} \mathrm{O}$ composition can be adjusted to accommodate changes in heat source temperature, but apparently no such modification was carried out to compensate for the $2{ }^{\circ} \mathrm{C}$ lower brine temperature. It should also be noted that the plant had been in 
operation for a relatively short period, some 15 months, when these test data were recorded. In reporting their performance data, the authors (Mlcak et al., 2002) claim that turbine performance had deteriorated and they applied a correction factor to the observed output. They also corrected for the lower brine inlet temperature and for "auxiliary electrical users" because of the lower inlet brine temperature. Although no details are given for each of these corrections, they state that the most significant correction arises from the lower brine inlet temperature. In this way, they were able to raise the output from the observed value of $1696 \mathrm{~kW}$ to $1959 \mathrm{~kW}$, an increase of $263 \mathrm{~kW}$. In this paper, the actual observed uncorrected output has been used in the comparison with the Brady plant.

It should be emphasized that, for the data point analyzed, the only thermodynamic difference between the Húsavík plant design conditions and the operating conditions was the $2{ }^{\circ} \mathrm{C}$ lower brine inlet temperature. Let us examine a few scenarios to try to understand the $334 \mathrm{~kW}$ shortfall in power output.

First, the $2{ }^{\circ} \mathrm{C}$ lower brine temperature causes a reduction in the incoming exergy of only $3 \%$, but the drop in power (and the drop in efficiency) amounts to $16.5 \%$. Thus, the power and efficiency decreases are much larger percentage-wise than the drop in exergy being supplied to the plant.

Additionally, we recall that the plant had an actual thermal efficiency of $10.6 \%$. Let us assume that the $2{ }^{\circ} \mathrm{C}$ deficiency in brine inlet temperature may be made up by heating the brine from some heat source. The amount of heat required is given by:

$$
\dot{Q}=\dot{m} \Delta h=\dot{m}\left(h_{124}{ }^{\circ} \mathrm{C}-h_{122}{ }^{\circ} \mathrm{C}\right)=90 \mathrm{~kg} / \mathrm{s} \times(520.73-512.21) \mathrm{kJ} / \mathrm{kg}=766.8 \mathrm{~kW}
$$

If we allow that $10.6 \%$ of this heat can be converted into useful work, this would yield only $81.3 \mathrm{~kW}$. Even if we were to use the design thermal efficiency of $12.1 \%$, the added output would amount to $92.8 \mathrm{~kW}$. Both of these values are much less than the $334 \mathrm{~kW}$ shortfall, leaving a discrepancy of $241-253 \mathrm{~kW}$ between design and actual performance.

Another approach would be to use the exergetic efficiency. The plant has an actual exergetic efficiency of $23.1 \%$; the design value is $26.8 \%$. The difference in the rate of incoming exergy between a $124^{\circ} \mathrm{C}$ brine and one at $122^{\circ} \mathrm{C}$ is $231.03 \mathrm{~kW}$. Using the two conversion efficiencies we find that the added output would come to 53.4 or $61.9 \mathrm{~kW}$, depending on whether we use the actual or the design efficiency. Again, we are left with a discrepancy of $272-281 \mathrm{~kW}$ between design and actual performance.

As mentioned earlier, the authors stated that the brine temperature effect involved the largest of the corrections. Thus, we are left with the conclusion that neither a First Law nor a Second Law analysis can account for the difference between the design and actual performance of the Húsavík plant.

The larger, $14^{\circ} \mathrm{C}$, difference between the temperature of the inlet brines for the Húsavík and Brady plants, $122^{\circ} \mathrm{C}$ versus $108^{\circ} \mathrm{C}$, will now be examined. Assuming a common dead-state temperature of $5{ }^{\circ} \mathrm{C}$, this causes a difference in incoming specific exergy of $16.88 \mathrm{~kJ} / \mathrm{kg}$ or $26.1 \%$ in favor of the Húsavík plant. This author has examined a wide variety of geothermal power plants including plants of flash, binary, and hybrid technology. For each plant the exergetic efficiency was calculated and plotted as a function of the incoming specific exergy of the geofluid, be it liquid, vapor or two-phase mixture. Some of these plants were detailed earlier in this paper. Table 8 summarizes the findings; Fig. 7 is a plot of the results. The conclusion is that there is no trend among the data. It is the sophistication of 
Table 8

Geothermal power plant exergetic efficiencies (in order of increasing efficiency)

\begin{tabular}{llcc}
\hline Technology & Plant name & $\begin{array}{l}\text { Specific exergy } \\
\text { input (kJ/kg) }\end{array}$ & $\begin{array}{l}\text { Exergetic } \\
\text { efficiency }(\%)\end{array}$ \\
\hline Binary & Brady bottoming (p.m. data) & 36.70 & 16.3 \\
Binary & Brady bottoming (a.m. data) & 49.86 & 17.9 \\
Binary: recuperated & Rotokawa & 227.96 & 18.7 \\
Binary & Nigorikawa (Mori) pilot & 92.77 & 21.6 \\
Binary & Kalina KCS-34, Husavik & 81.49 & 23.1 \\
Binary: simple & Rotokawa & 646.71 & 27.8 \\
Single-flash & Blundell & 278.67 & 35.6 \\
Hybrid flash-binary & Rotokawa & 461.45 & 42.0 \\
Binary: dual-level & Heber SIGC & 125.84 & 43.4 \\
Double-flash & Beowawe & 205.14 & 46.0 \\
Binary: flash evaporator & Otake pilot & 126.65 & 53.9 \\
\hline
\end{tabular}

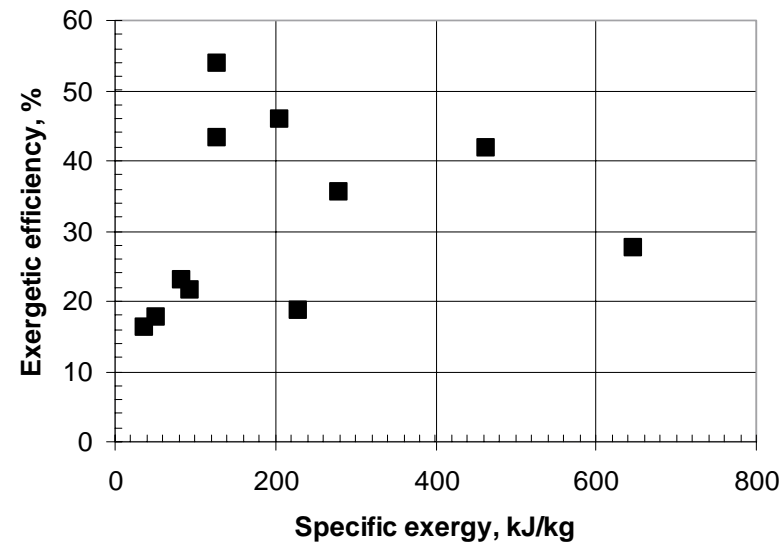

Fig. 7. Geothermal power plant exergetic efficiency vs. specific exergy of incoming geofluid: various plants.

the plant design that determines the efficiency, irrespective of the incoming exergy. Thus, it is not possible to draw a conclusion regarding the effect of the $14{ }^{\circ} \mathrm{C}$ temperature difference between the Húsavík and Brady plants without recourse to a complete process simulator for the Kalina cycle, something that was not available to this author.

\section{Conclusions}

Geothermal binary plants are relatively poor converters of heat into work. First Law or thermal efficiencies typically lie in the range of $8-12 \%$. As a consequence, a 1-2 percentage point improvement in power output translates into a gain of about 10-20\% in efficiency.

The results show that binary plants can operate with very high Second Law or exergetic efficiencies even when the motive fluids are low-temperature and low-exergy. Exergetic 
efficiencies of $40 \%$ or greater have been achieved in certain plants with geofluids having specific exergies of $200 \mathrm{~kJ} / \mathrm{kg}$ or lower. The main design feature leading to a high Second Law efficiency lies in the design of the heat exchangers to minimize the loss of exergy during heat transfer processes. Another important feature that can result in a high Second Law efficiency is the availability of low-temperature cooling water that allows a once-through system for waste heat rejection.

Finally, this analysis demonstrates that broad claims of $15-50 \%$ more power output for the same heat input for Kalina cycles relative to organic Rankine binary cycles are not being achieved for plants in operation. Under simulated identical conditions of ambient temperature and cooling systems, the calculated difference in performance is about $3 \%$ in favor of a Kalina cycle. It is uncertain whether the difference in inlet brine exergy favoring the Kalina cycle in this study may have played a role in the efficiency advantage of the Kalina over the ORC. It must be pointed out that ORC geothermal technology is mature, with hundreds of megawatts of various kinds of cycles installed throughout the world, whereas the Húsavík plant is the only commercial Kalina cycle in operation so far.

\section{Acknowledgements}

The author would like to acknowledge the cooperation of Ormat International in providing plant data for this study. The author benefited from discussions with Zvi Kreiger and Daniel Schochet.

\section{References}

Bosnjakovic, F., 1965. Technical Thermodynamics. Holt, Rinehart and Winston, New York, pp. 489-509 (Trans. P.L. Blackshear Jr.).

DiPippo, R., Marcille, D.F., 1984. Exergy analysis of geothermal power plants. Geothermal Res. Council Trans. $8,47-52$.

DiPippo, R., 1980a. Geothermal Energy as a Source of Electricity. U.S. Department of Energy, DOE/RA/28320-1, pp. 172-176.

DiPippo, R., 1980b. Geothermal Energy as a Source of Electricity. U.S. Department of Energy, DOE/RA/28320-1, pp. 176-177.

DiPippo, R., 1987. Exergy analysis of combined electricity and direct-heat geothermal flash-steam plants. Geothermal Res. Council Trans. 11, 411-416.

DiPippo, R., 1994. Second Law analysis of flash-binary and multilevel binary geothermal power plants. Geothermal Res. Council Trans. 18, 505-510.

Ettinger, T., Brugman, J., 1992. Brady Hot Springs geothermal power plant. Geothermal Res. Council Bull. 21 (8), 258-260.

GRC Bulletin, 1993. New geothermal facility exceeds production expectations. Geothermal Res. Council Bull. 22 (10), 281-282.

Kalina, A.I., Liebowitz, H.M., 1989. Application of the Kalina cycle technology to geothermal power generation. Geothermal Res. Council Trans. 13, 605-611.

Kalina, A.I., Liebowitz, H.M., 1994. Applying Kalina cycle technology to high enthalpy geothermal resources. Geothermal Res. Council Trans. 18, 531-536.

Kalina, A.I., Liebowitz, H.M., Lazzeri, L., Diotti, F., 1995. Recent development in the application of Kalina cycle for geothermal plants. Proceedings of World Geothermal Congress, Florence, vol. 3, 1995, pp. 2093-2096. 
Kreiger, Z., Sponsler, E., 2002. Improvement to the Brady geothermal project to compensate for decline in reservoir performance. Geothermal Res. Council Trans. 26, 735-738.

Lewis, W.E., Ralph, M., 2002. A DOE-funded design study for pioneer baseload application of an advanced geothermal binary cycle at a Utility Plant in Western Utah. Geothermal Res. Council Trans. 26, 695-699.

Liebowitz, H.M., Markus, D.W., 1990. Economic performance of geothermal power plants using the Kalina cycle technology. Geothermal Res. Council Trans. 14 (Part II), 1037-1042.

Liebowitz, H.M., Mlcak, H.A., 1999. Design of a 2 MW Kalina cycle ${ }^{\circledR}$ binary module for installation in Húsavík, Iceland. Geothermal Res. Council Trans. 23, 75-80.

Mlcak, H.A., 2002. Kalina cycle ${ }^{\circledR}$ concepts for low temperature geothermal. Geothermal Res. Council Trans. 26, 707-713.

Mlcak, H.A., Mirolli, M., Hjartarson, H., Húsavíkur, O., Ralph, M., 2002. Notes from the north: a report on the debut year of the 2 MW Kalina cycle ${ }^{\circledR}$ geothermal power plant in Húsavík, Iceland. Geothermal Res. Council Trans. 26, 715-718.

Sponsler, E., 2002. Personal communication, August 27. 